\title{
Transforming Masculinities
}

Baseline

\section{Men's Survey}

Today's date

Day ${ }^{\prime} \overline{\text { Month }}^{\prime} \overline{\text { Year }}$

Section 1: Background Characteristics. Let's start with some questions about you:

\begin{tabular}{|c|c|c|c|}
\hline No. (Tablet) & Questions and filters & Coding categories & $\begin{array}{c}\text { Skip } \\
\text { to }\end{array}$ \\
\hline \multicolumn{4}{|c|}{ SECTION 1: Background characteristics } \\
\hline (1) & Consent form & $\begin{array}{l}\text { Yes } \\
\text { No } \ldots \ldots \ldots \ldots 1\end{array}$ & \\
\hline (2) & Interviewer code & Interviewer code: & \\
\hline
\end{tabular}




\begin{tabular}{|c|c|c|c|}
\hline No. (Tablet) & Questions and filters & Coding categories & $\begin{array}{c}\text { Skip } \\
\text { to }\end{array}$ \\
\hline (3) & $\begin{array}{l}\text { What is the name of the church where you } \\
\text { are a member? }\end{array}$ & 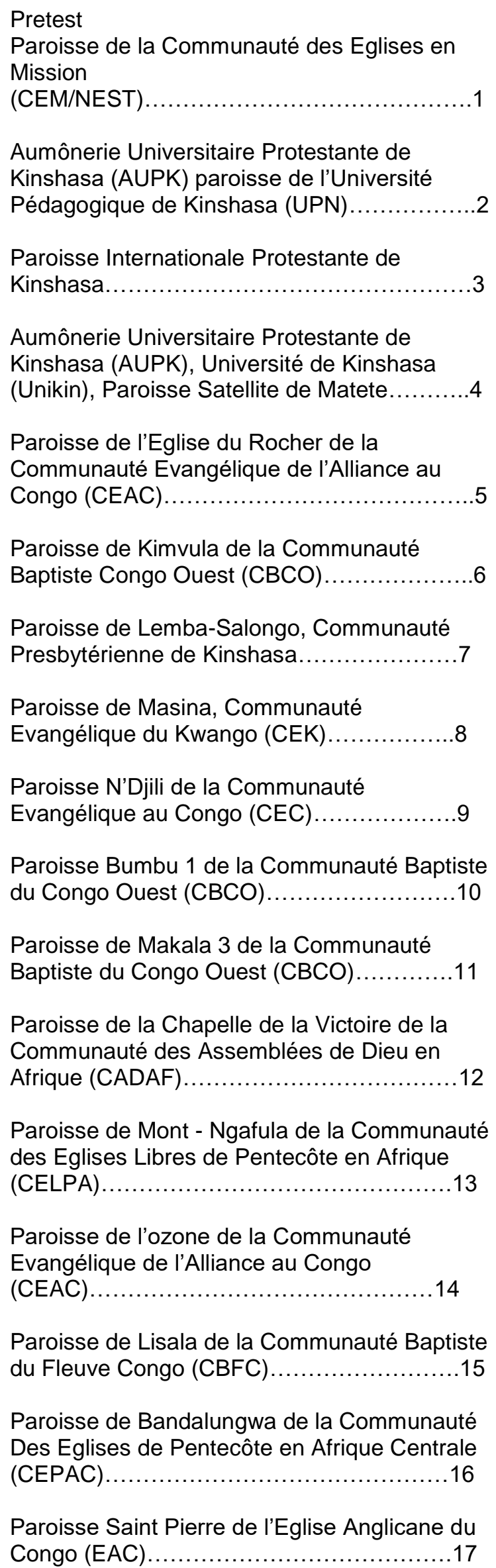 & \\
\hline
\end{tabular}




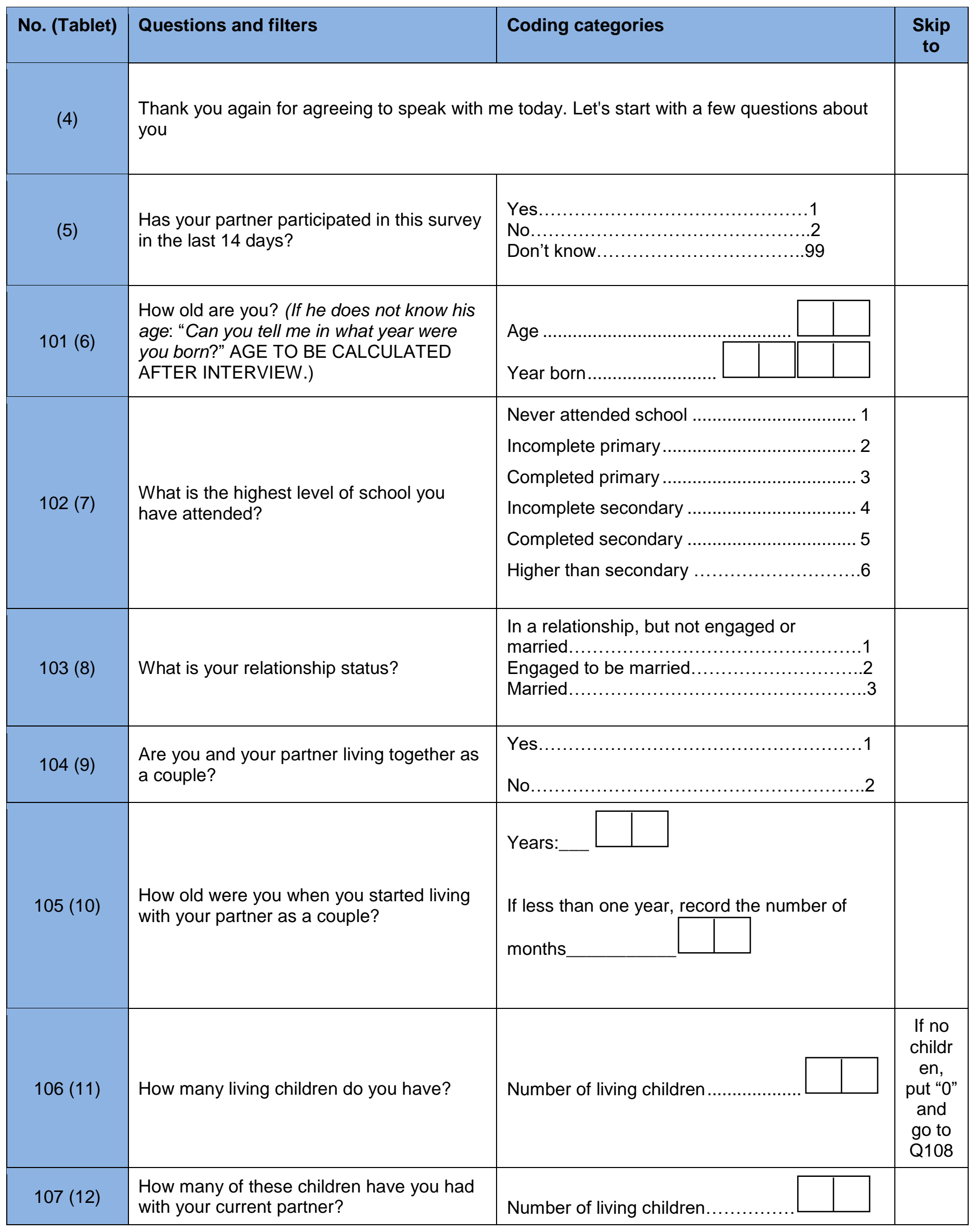




\begin{tabular}{|c|c|c|c|}
\hline No. (Tablet) & Questions and filters & Coding categories & $\begin{array}{c}\text { Skip } \\
\text { to }\end{array}$ \\
\hline $108(13)$ & What is your religion? & 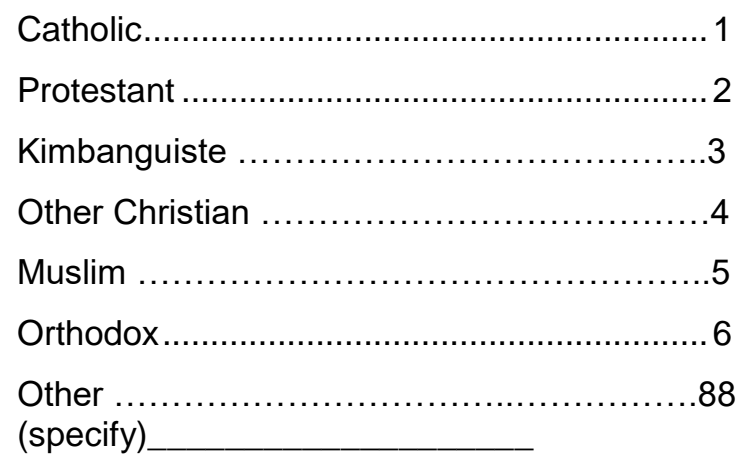 & \\
\hline $109(14)$ & $\begin{array}{l}\text { How would you describe your typical } \\
\text { attendance at your church for services or } \\
\text { prayers? }\end{array}$ & 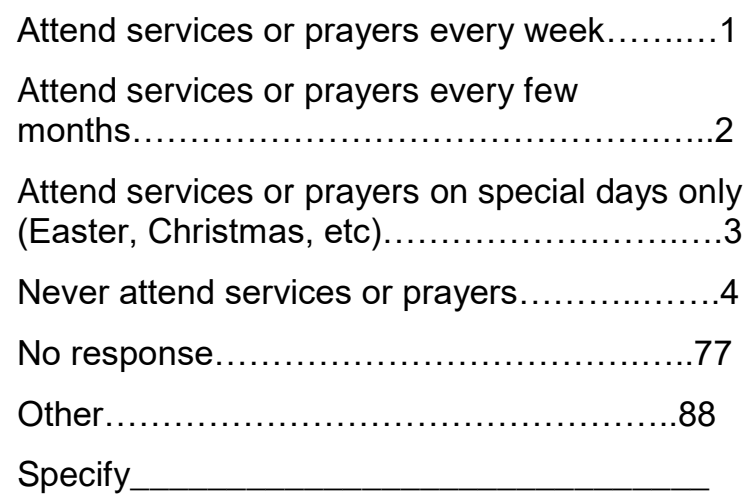 & \\
\hline $110(15)$ & How important is your religion to you? & 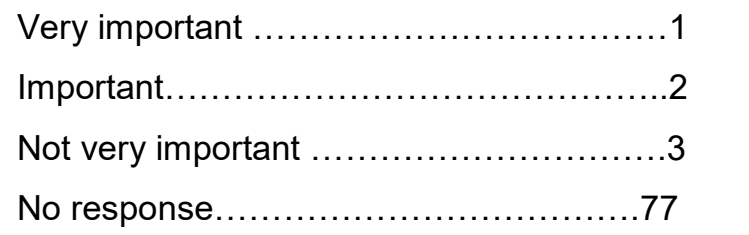 & \\
\hline $111(16)$ & What is your ethnicity? & 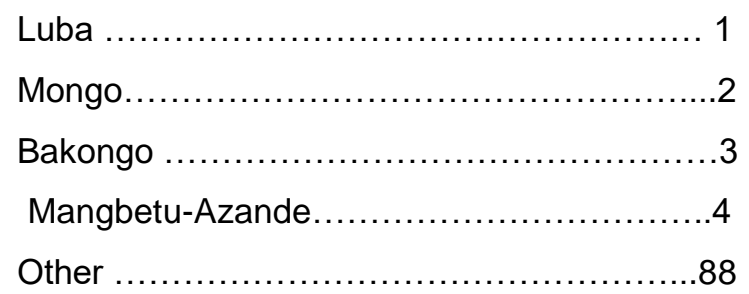 & \\
\hline $112(17)$ & $\begin{array}{l}\text { Who are the adults that live in the same } \\
\text { household with you/you and your partner? } \\
\text { MULTIPLE OPTIONS POSSIBLE. }\end{array}$ & 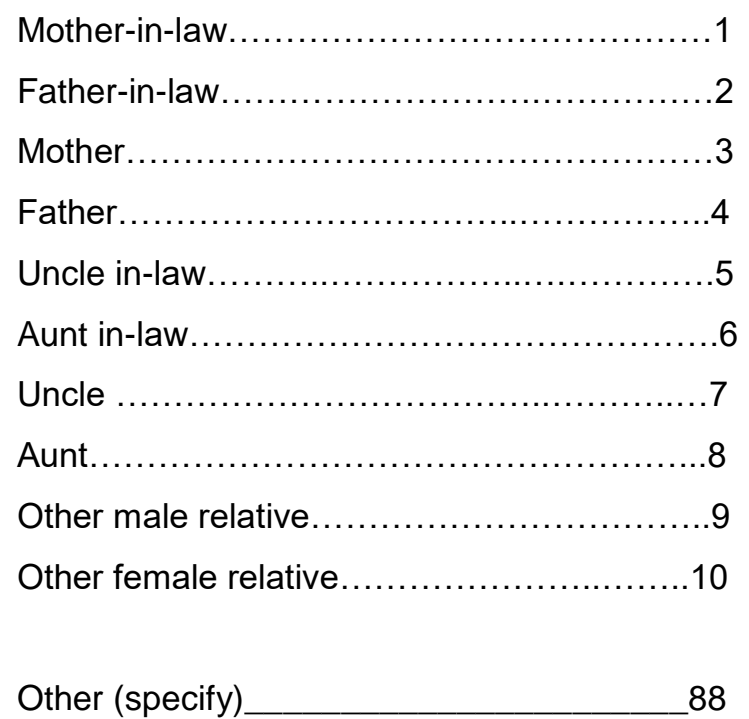 & \\
\hline
\end{tabular}




\begin{tabular}{|c|c|c|c|}
\hline No. (Tablet) & Questions and filters & Coding categories & $\begin{array}{c}\text { Skip } \\
\text { to }\end{array}$ \\
\hline $113(18)$ & $\begin{array}{l}\text { How often has the household had } \\
\text { problems in satisfying the food needs in the } \\
\text { last } 12 \text { months? }\end{array}$ & 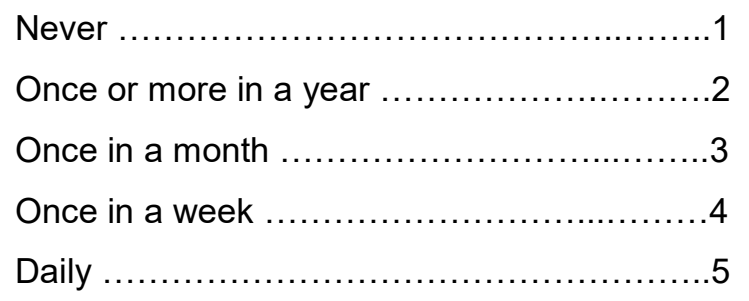 & \\
\hline \multicolumn{4}{|c|}{ SECTION 2: Family Planning } \\
\hline (19) & \multicolumn{2}{|c|}{$\begin{array}{l}\text { Now I would like to talk to you about family planning - the ways or methods couples use to } \\
\text { delay or avoid pregnancy }\end{array}$} & \\
\hline $201(20)$ & $\begin{array}{l}\text { Is your wife pregnant, or do you think she } \\
\text { is pregnant? }\end{array}$ & Yes & $\begin{array}{l}\text { If } \\
\text { Yes, } \\
\text { go to } \\
\text { Q205 }\end{array}$ \\
\hline $202(21)$ & $\begin{array}{l}\text { Are you or your wife currently doing } \\
\text { something or using any method to delay or } \\
\text { avoid getting pregnant? }\end{array}$ & Yes & $\begin{array}{l}\rightarrow \text { Go } \\
\text { to } \\
\text { Q204 }\end{array}$ \\
\hline $203(22)$ & $\begin{array}{l}\text { Which method are you or your wife using? } \\
\text { MULTIPLE RESPONSES POSSIBLE. } \\
\text { DO NOT READ THE LIST. } \\
\text { CIRCLE THE LETTER FOR EACH } \\
\text { MENTIONED. }\end{array}$ & 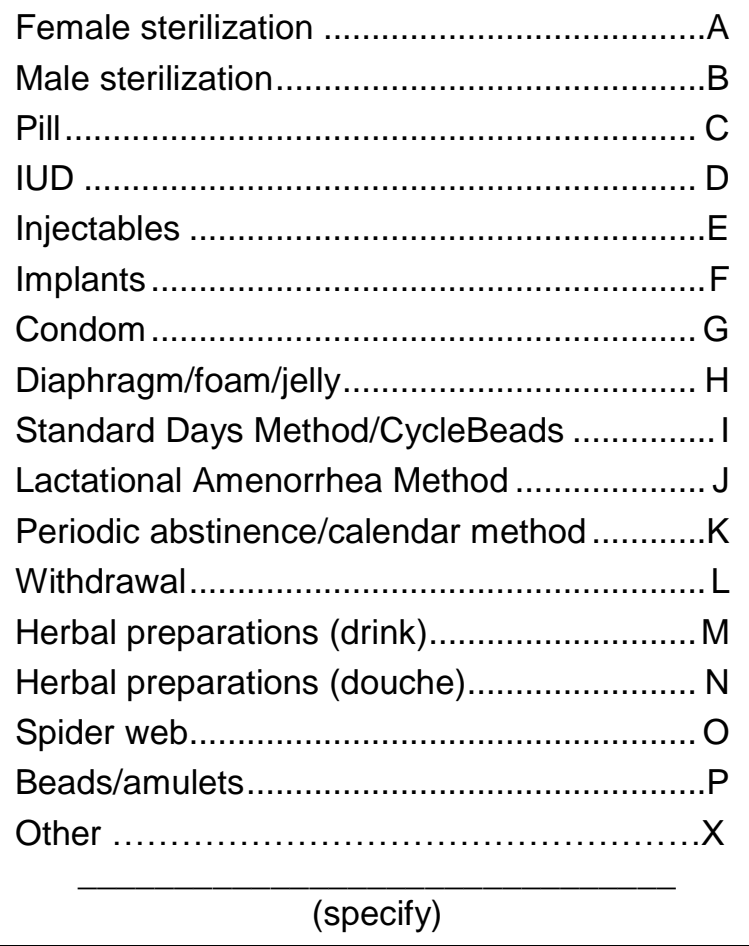 & \\
\hline $204(23)$ & $\begin{array}{l}\text { You have said that you are not currently } \\
\text { using a method to avoid pregnancy. Could } \\
\text { you tell me why you are not using a } \\
\text { method? } \\
\text { Any other reason? }\end{array}$ & 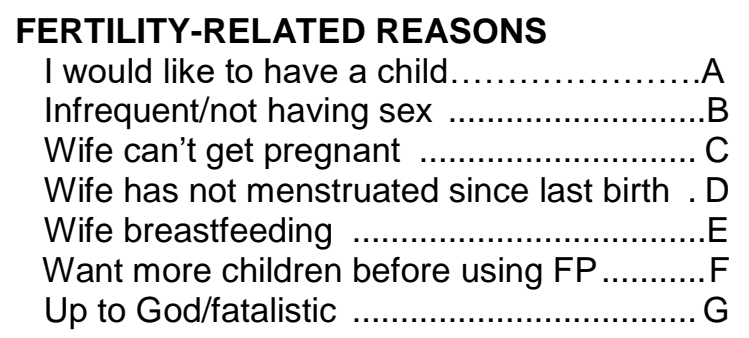 & \\
\hline
\end{tabular}




\begin{tabular}{|c|c|c|c|}
\hline No. (Tablet) & Questions and filters & Coding categories & $\begin{array}{c}\text { Skip } \\
\text { to }\end{array}$ \\
\hline & \multirow[t]{3}{*}{$\begin{array}{l}\text { MULTIPLE RESPONSES POSSIBLE. } \\
\text { DO NOT READ THE LIST. } \\
\text { CIRCLE THE LETTER FOR EACH } \\
\text { MENTIONED. }\end{array}$} & 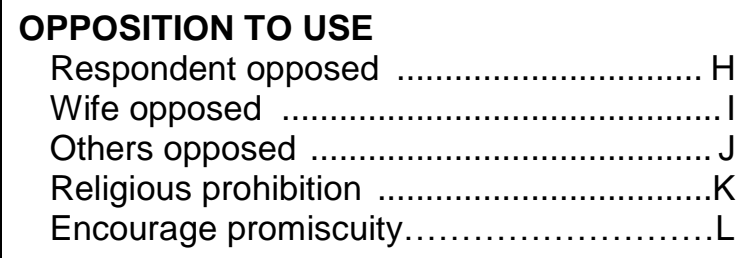 & \\
\hline & & $\begin{array}{l}\text { LACK OF KNOWLEDGE } \\
\text { Knows no method } \\
\text { Knows no source }\end{array}$ & \\
\hline & & 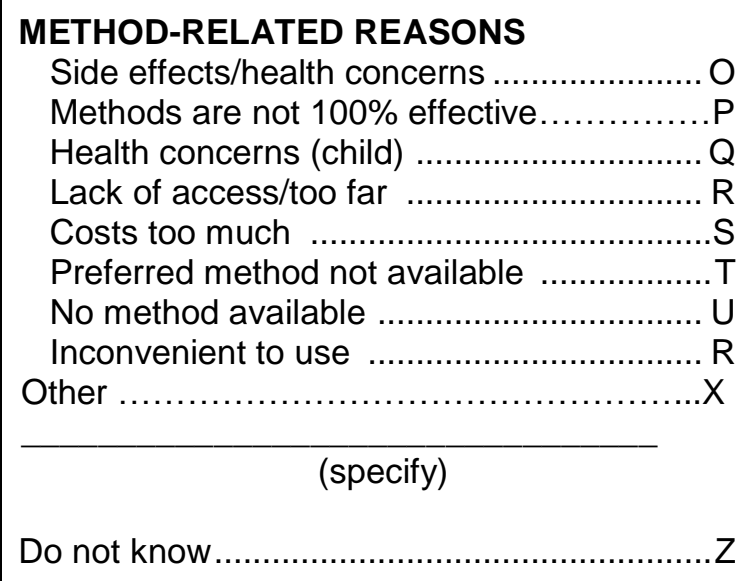 & \\
\hline $205(24)$ & $\begin{array}{l}\text { Have you or your wife ever done or used } \\
\text { any method to delay or avoid getting } \\
\text { pregnant? }\end{array}$ & Yes & $\begin{array}{l}\text { Tf No, } \\
\text { Go to } \\
\text { Q207 }\end{array}$ \\
\hline $206(25)$ & $\begin{array}{l}\text { Which method have you used in the past? } \\
\text { CIRCLE ALL MENTIONED }\end{array}$ & 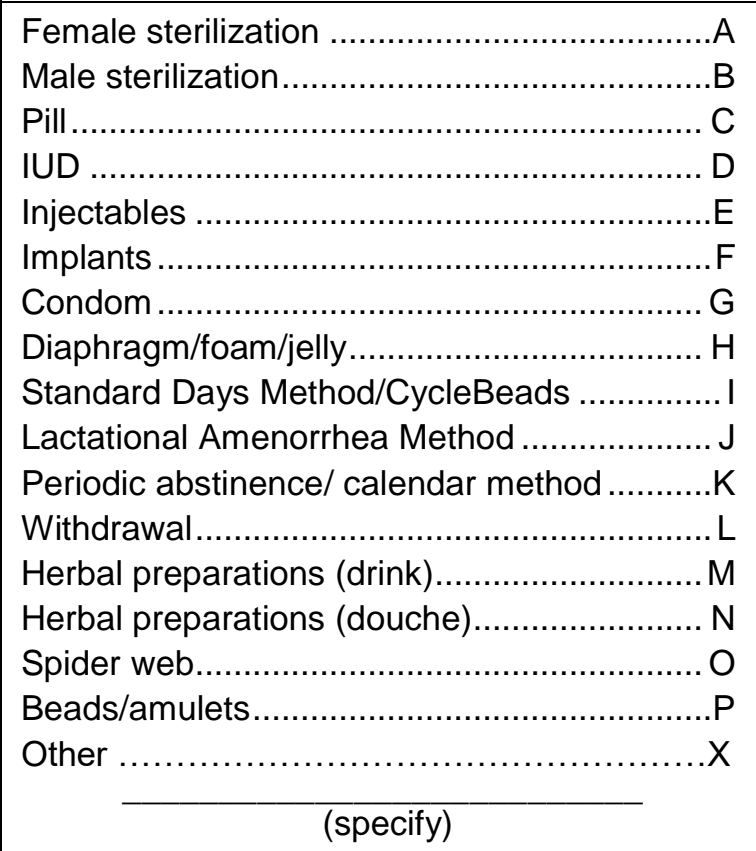 & \\
\hline
\end{tabular}




\begin{tabular}{|c|c|c|c|}
\hline No. (Tablet) & Questions and filters & Coding categories & $\begin{array}{c}\text { Skip } \\
\text { to }\end{array}$ \\
\hline $207(26)$ & $\begin{array}{l}\text { How likely would you say it is that you and } \\
\text { your wife would use a modern method of } \\
\text { family planning in the future? }\end{array}$ & 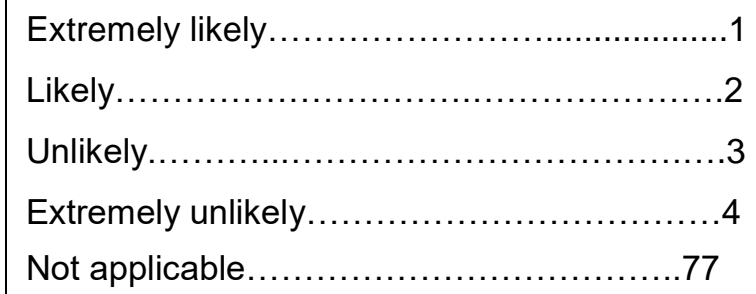 & \\
\hline \multicolumn{4}{|c|}{ Access to Family Planning } \\
\hline$(27)$ & \multicolumn{2}{|c|}{$\begin{array}{c}\text { I'm now going to read you a series of statements regarding access to family planning. For } \\
\text { each statement, I will ask you to respond yes or no. When I say modern method of family } \\
\text { planning, I mean a method that you have obtained in a pharmacy, health facility or from a } \\
\text { Community Health Worker. }\end{array}$} & \\
\hline $208(28)$ & $\begin{array}{l}\text { Modern methods of family planning are } \\
\text { available in the community where I live. }\end{array}$ & Yes & \\
\hline $209(29)$ & $\begin{array}{l}\text { I have transportation to get to a health } \\
\text { facility that provides family planning } \\
\text { methods. }\end{array}$ & Yes & \\
\hline $210(30)$ & $\begin{array}{l}\text { I have the means to purchase modern } \\
\text { methods of family planning if I want to use } \\
\text { them. }\end{array}$ & Yes & \\
\hline $211(31)$ & $\begin{array}{l}\text { I have enough information to make a } \\
\text { decision about which modern method to } \\
\text { use if I wanted to use one. }\end{array}$ & Yes No & \\
\hline $212(32)$ & $\begin{array}{l}\text { I will give my wife money to purchase a } \\
\text { modern method of family planning. }\end{array}$ & 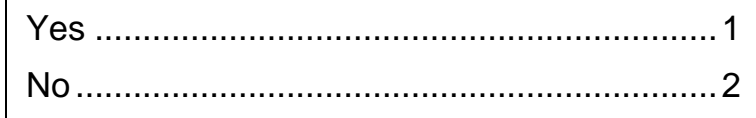 & \\
\hline \multicolumn{4}{|c|}{ SECTION 3: Family Planning Norms } \\
\hline \multicolumn{4}{|c|}{ Family Planning Outcome Expectations } \\
\hline (33) & \multicolumn{2}{|c|}{$\begin{array}{l}\text { I will read several statements. For each statement please let me know how much you agree } \\
\text { with the statement - strongly agree, agree, disagree or strongly disagree. }\end{array}$} & \\
\hline $301(34)$ & $\begin{array}{l}\text { If I use a modern method of family planning } \\
\text { (for example a condom, Jadelle, } \\
\text { sterilization, etc.) I will avoid an unwanted } \\
\text { pregnancy. }\end{array}$ & 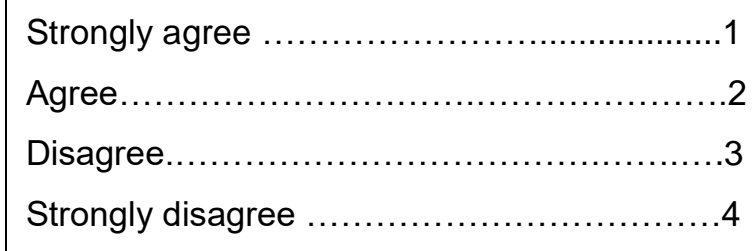 & \\
\hline $302(35)$ & $\begin{array}{l}\text { If I use a modern method of family planning } \\
\text { I will have difficulty getting my wife } \\
\text { pregnant in the future. }\end{array}$ & 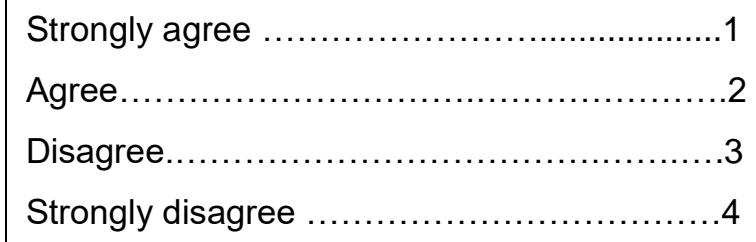 & \\
\hline
\end{tabular}




\begin{tabular}{|c|c|c|c|}
\hline No. (Tablet) & Questions and filters & Coding categories & $\begin{array}{c}\text { Skip } \\
\text { to }\end{array}$ \\
\hline $303(36)$ & $\begin{array}{l}\text { If I use a modern method of family } \\
\text { planning, it would not be against my } \\
\text { religion. }\end{array}$ & 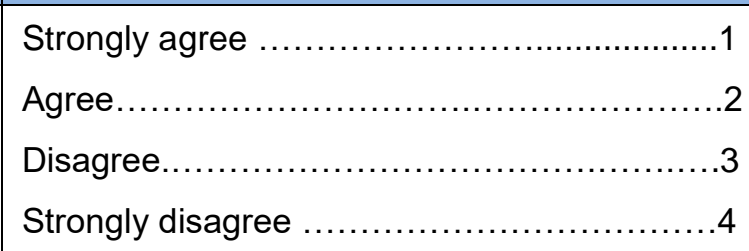 & \\
\hline $304(37)$ & $\begin{array}{l}\text { If I use a condom I will have less sexual } \\
\text { pleasure. }\end{array}$ & 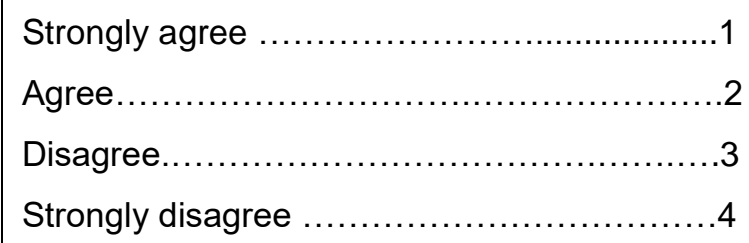 & \\
\hline $305(38)$ & $\begin{array}{l}\text { If I use a modern method of family planning } \\
\text { I will get a reputation for being } \\
\text { promiscuous. }\end{array}$ & 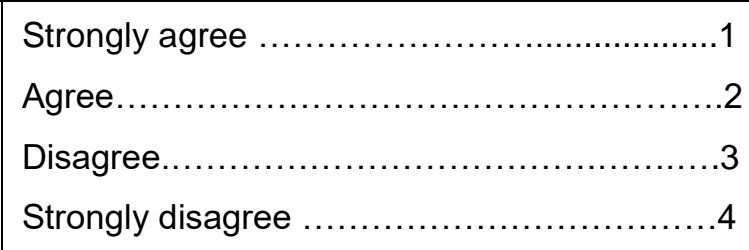 & \\
\hline $306(39)$ & $\begin{array}{l}\text { If I use a modern method of family planning } \\
\text { I will experience negative side effects. }\end{array}$ & 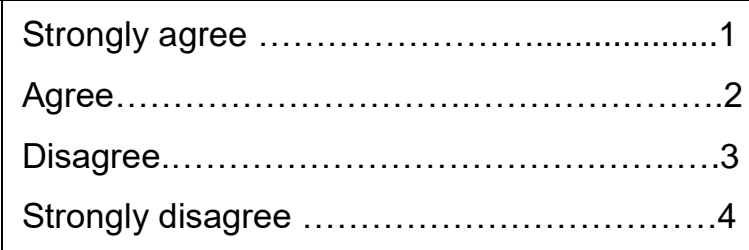 & \\
\hline $307(40)$ & $\begin{array}{l}\text { If my wife mentions using a modern } \\
\text { method of family planning I will support her. }\end{array}$ & 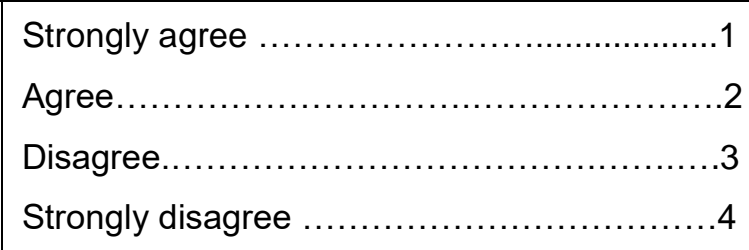 & \\
\hline \multicolumn{4}{|c|}{ Family Planning: Attitudes, Injunctive Norms and Intentions } \\
\hline$(41)$ & $\begin{array}{l}\text { I will read several statements. For each sta } \\
\text { matters and tell me what you think. I will re }\end{array}$ & $\begin{array}{l}\text { ement, consider your own feelings about these } \\
d \text { each statement and the response options. }\end{array}$ & \\
\hline $308(42)$ & $\begin{array}{l}\text { For me, avoiding an unwanted pregnancy } \\
\text { is... }\end{array}$ & 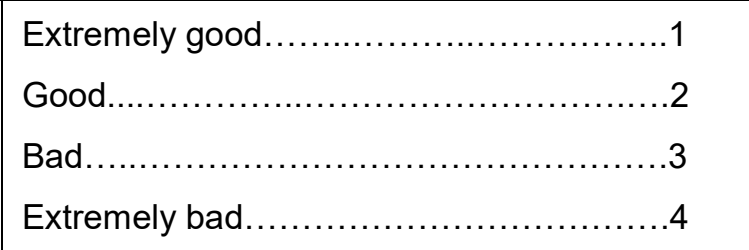 & \\
\hline $309(43)$ & For me, sexual pleasure is... & 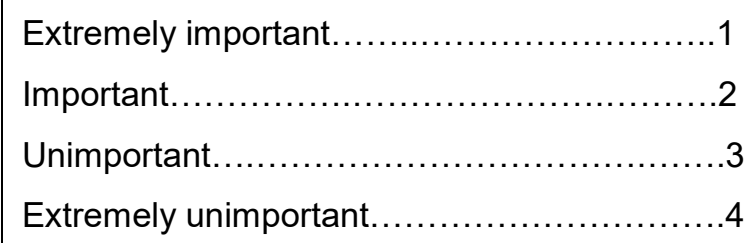 & \\
\hline $310(44)$ & $\begin{array}{l}\text { For my wife (partner), to use a modern } \\
\text { method of family planning is .... }\end{array}$ & $\begin{array}{l}\text { Extremely valuable to my wife's health......... } \\
\text { Valuable to my wife's health.................... } \\
\text { Not very valuable to my wife's health........... } \\
\text { Not at all valuable to my wife's health..........4 }\end{array}$ & \\
\hline
\end{tabular}




\begin{tabular}{|c|c|c|c|}
\hline No. (Tablet) & Questions and filters & Coding categories & $\begin{array}{c}\text { Skip } \\
\text { to }\end{array}$ \\
\hline $311(45)$ & $\begin{array}{l}\text { For me, to use a modern method of family } \\
\text { planning is .... }\end{array}$ & $\begin{array}{l}\text { Extremely valuable to my own health.........1 } \\
\text { Valuable to my own health.....................2 } \\
\text { Not very valuable to my own health..........3 } \\
\text { Not at all valuable to my own health..........4 }\end{array}$ & \\
\hline $312(46)$ & $\begin{array}{l}\text { For my wife, experiencing negative side } \\
\text { effects of a modern method of family } \\
\text { planning is ... }\end{array}$ & 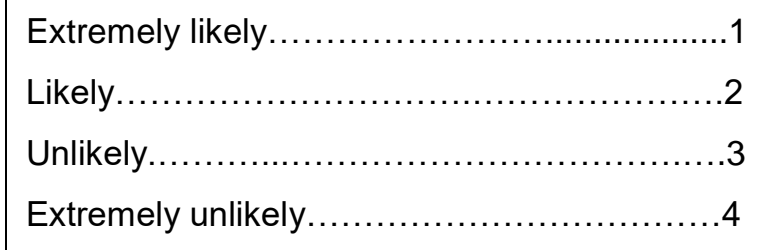 & \\
\hline \multicolumn{4}{|c|}{ Family Planning Self efficacy } \\
\hline$(47)$ & \multicolumn{2}{|c|}{$\begin{array}{l}\text { Now I will read a few statements. For each one, I want you to tell me how confident you feel } \\
\text { you could do each of these things. }\end{array}$} & \\
\hline $313 a(48)$ & $\begin{array}{l}\text { I can use a modern method of family } \\
\text { planning correctly to avoid or delay a } \\
\text { pregnancy. }\end{array}$ & 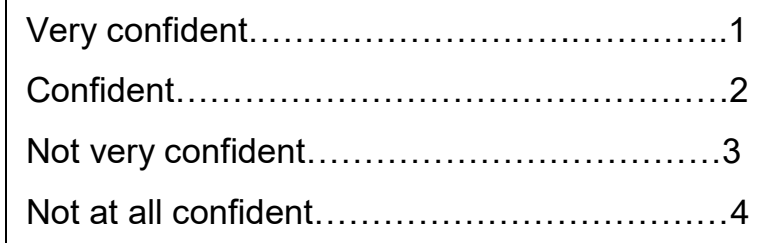 & \\
\hline $313 b(49)$ & $\begin{array}{l}\text { I can use a modern method of family } \\
\text { planning correctly all the time to delay or } \\
\text { avoid pregnancy, even if the faith leaders } \\
\text { in my church disagree. }\end{array}$ & 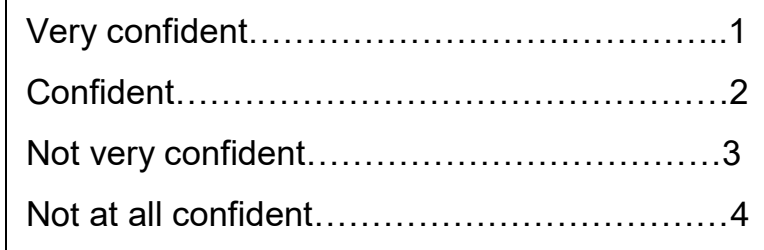 & \\
\hline $313 c(50)$ & $\begin{array}{l}\text { I can use a modern method of family } \\
\text { planning correctly all the time to delay or } \\
\text { avoid pregnancy. }\end{array}$ & 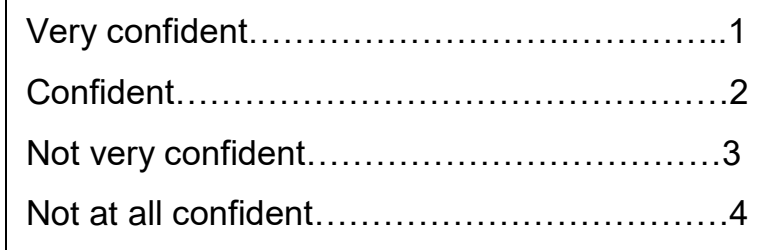 & \\
\hline $313 d(51)$ & $\begin{array}{l}\text { I can suggest using a modern method of } \\
\text { family planning to my partner. }\end{array}$ & 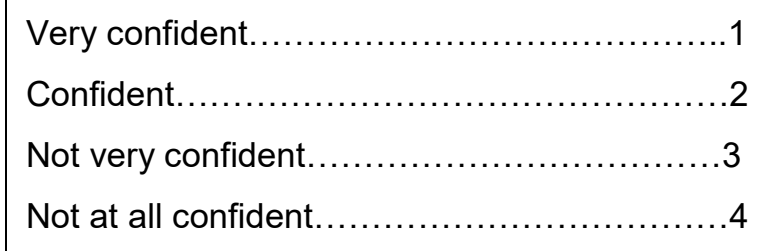 & \\
\hline \multicolumn{4}{|c|}{ Family Planning: Injunctive Norms } \\
\hline (52) & \multicolumn{2}{|c|}{$\begin{array}{l}\text { For this next set of questions, I will read a series of statements. For each statement, I want to } \\
\text { know what you think people expect others to do. You can say strongly agree, agree, disagree } \\
\text { or strongly disagree. }\end{array}$} & \\
\hline $314(53)$ & $\begin{array}{l}\text { Members of this congregation think it is } \\
\text { appropriate for newly married couples to } \\
\text { use modern methods of family planning }\end{array}$ & 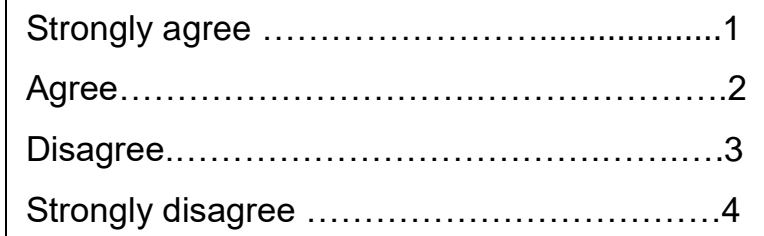 & \\
\hline
\end{tabular}




\begin{tabular}{|c|c|c|c|c|}
\hline \multicolumn{2}{|c|}{ No. (Tablet) } & Questions and filters & Coding categories & $\begin{array}{c}\text { Skip } \\
\text { to }\end{array}$ \\
\hline \multicolumn{2}{|c|}{$315(54)$} & $\begin{array}{l}\text { Members of this congregation think it is } \\
\text { appropriate for first time parents to use } \\
\text { modern methods of family planning }\end{array}$ & 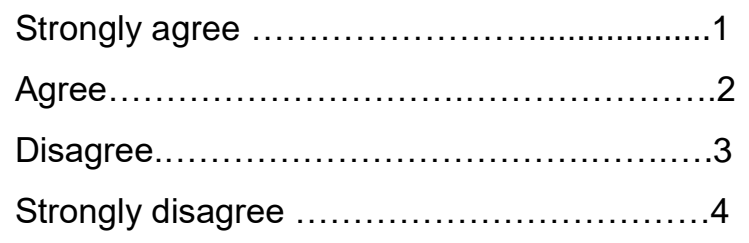 & \\
\hline \multicolumn{2}{|c|}{$316(55)$} & $\begin{array}{l}\text { Faith leaders in this congregation think it is } \\
\text { appropriate for first time parents to use a } \\
\text { modern method of family planning }\end{array}$ & 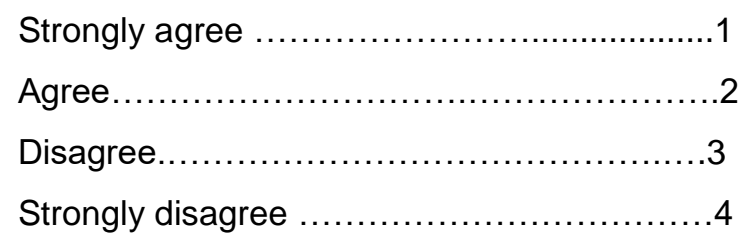 & \\
\hline \multicolumn{2}{|c|}{$317(56)$} & $\begin{array}{l}\text { Faith leaders think it is appropriate for } \\
\text { newly married couples to use a modern } \\
\text { method of family planning }\end{array}$ & 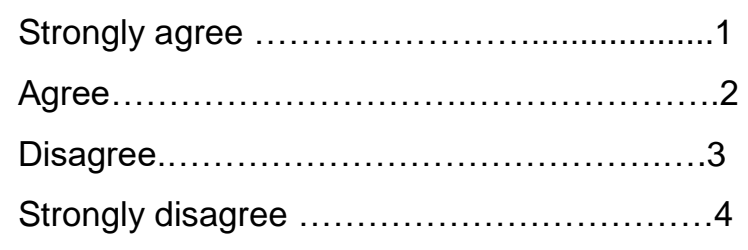 & \\
\hline \multicolumn{2}{|c|}{$318(57)$} & $\begin{array}{l}\text { It is appropriate for newly married couples } \\
\text { to use a modern method of family planning. }\end{array}$ & 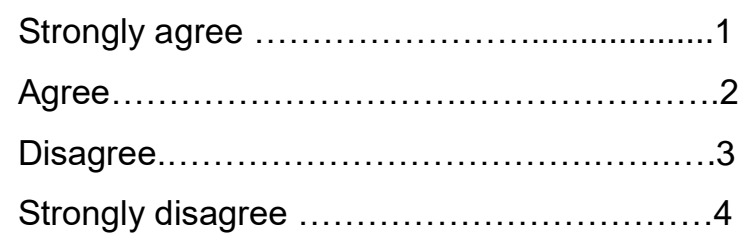 & \\
\hline \multicolumn{2}{|c|}{$319(58)$} & $\begin{array}{l}\text { It is appropriate for first time parents to use } \\
\text { a modern method of family planning. }\end{array}$ & 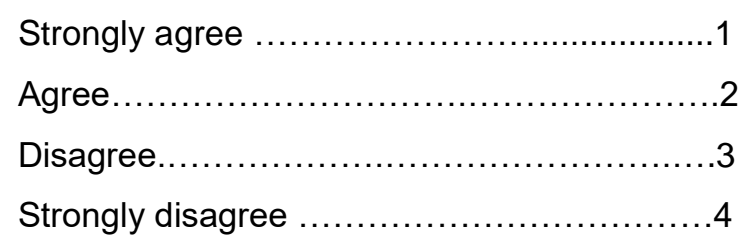 & \\
\hline \multicolumn{5}{|c|}{ Family Planning: Normative Beliefs } \\
\hline $\begin{array}{l}320 \\
(59)\end{array}$ & \multicolumn{2}{|c|}{$\begin{array}{l}\text { In matters related to family planning, whose } \\
\text { opinion matters to you? } \\
\text { DO NOT READ OPTIONS. } \\
\text { CHECK ALL OPTIONS THAT APPLY. }\end{array}$} & 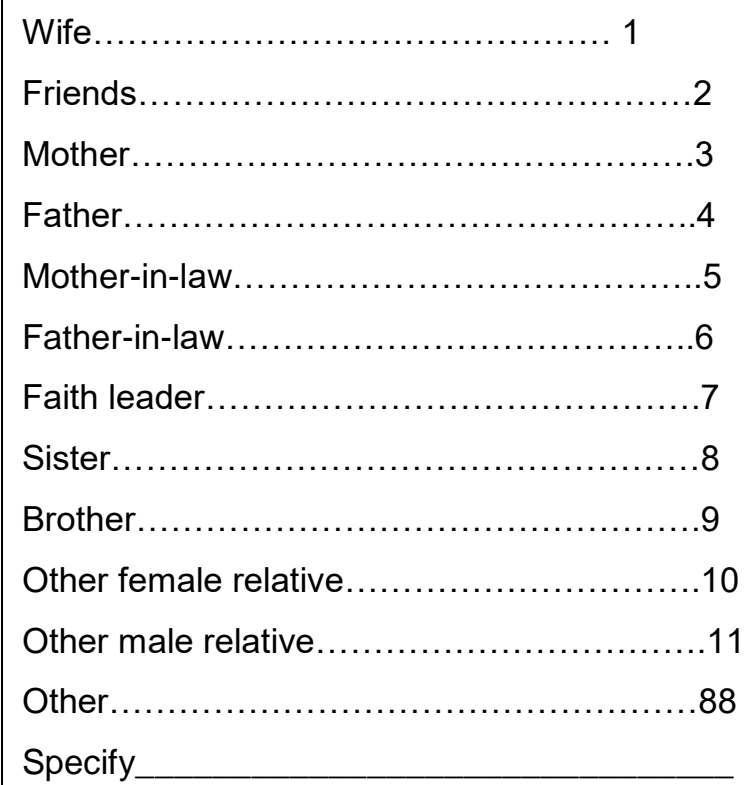 & \\
\hline
\end{tabular}




\begin{tabular}{|c|c|c|c|c|}
\hline \multicolumn{2}{|c|}{ No. (Tablet) } & \multirow{2}{*}{$\begin{array}{l}\text { Questions and filters } \\
\text { tters related to family planning, people } \\
\text { opinions are important to me think my wife } \\
\text { er) and I should use a modern method of } \\
\text { planning. }\end{array}$} & \multirow{2}{*}{ 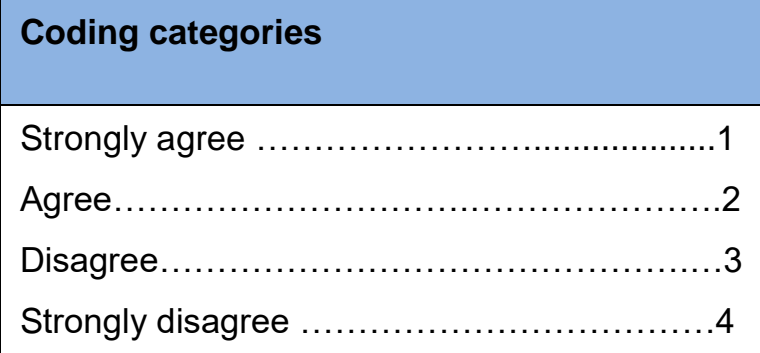 } & \multirow{2}{*}{$\begin{array}{c}\text { Skip } \\
\text { to }\end{array}$} \\
\hline $\begin{array}{l}321 \\
(60)\end{array}$ & $\begin{array}{l}\text { In matters related to family planning, people } \\
\text { whose opinions are important to me think my wife } \\
\text { (partner) and I should use a modern method of } \\
\text { family planning. }\end{array}$ & & & \\
\hline $\begin{array}{l}322 \\
(61)\end{array}$ & \multicolumn{2}{|c|}{$\begin{array}{l}\text { My wife (partner) thinks we, as a couple, should } \\
\text { use a modern method of family planning. }\end{array}$} & 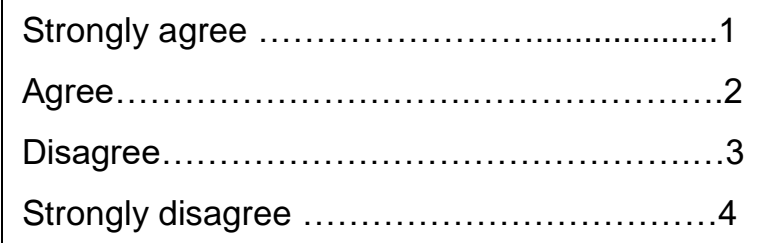 & \\
\hline $\begin{array}{l}323 \\
(62)\end{array}$ & \multicolumn{2}{|c|}{$\begin{array}{l}\text { Faith leaders in this congregation think my wife } \\
\text { (partner) and I should use a modern method of } \\
\text { family planning. }\end{array}$} & 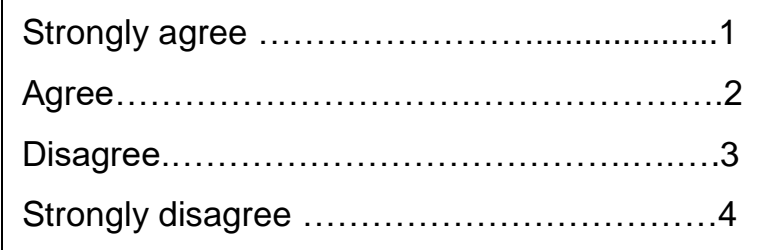 & \\
\hline \multicolumn{5}{|c|}{ Family Planning: Motivation to Comply } \\
\hline \multicolumn{2}{|c|}{$324(63)$} & $\begin{array}{l}\text { In matters related to family planning, how } \\
\text { important is it for you to do what your wife } \\
\text { (partner) wants you to do? }\end{array}$ & 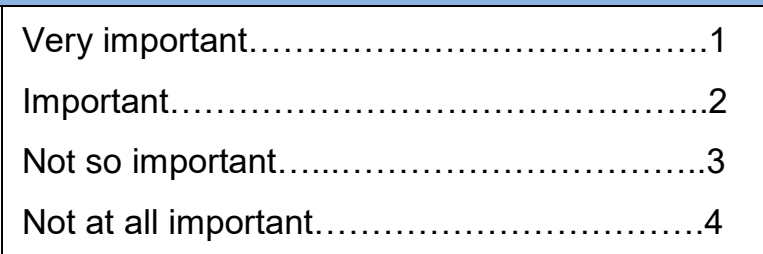 & \\
\hline \multicolumn{2}{|c|}{$325(64)$} & $\begin{array}{l}\text { In matters related to family planning, how } \\
\text { important is it for you to do what the faith } \\
\text { leaders in this congregation want you to do }\end{array}$ & 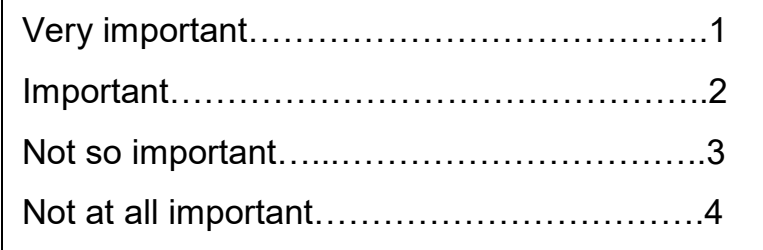 & \\
\hline \multicolumn{2}{|c|}{$326(65)$} & $\begin{array}{l}\text { In matters related to family planning, how } \\
\text { important is it for you to do what people } \\
\text { whose opinion matters want you to do? }\end{array}$ & 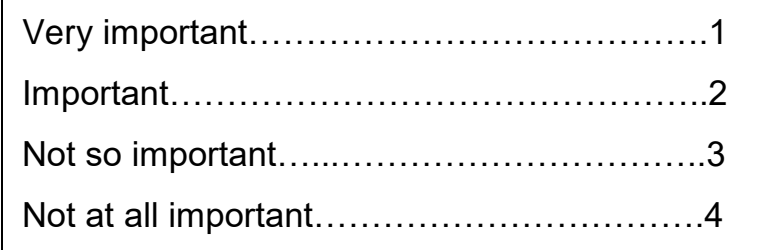 & \\
\hline \multicolumn{5}{|c|}{ Descriptive Norms on Family Planning } \\
\hline & & $\begin{array}{l}\text { Now I would like to know what people in you } \\
\text { normal or typical behavior when you respon } \\
\text { statements are true for most, many, some o }\end{array}$ & $\begin{array}{l}\text { congregation actually do. Think about what is } \\
\text { to these statements. Do you think that these } \\
\text { none of the people in this congregation? }\end{array}$ & \\
\hline 327 & & $\begin{array}{l}\text { Newly married couples in your } \\
\text { congregation use a modern method of } \\
\text { family planning. }\end{array}$ & 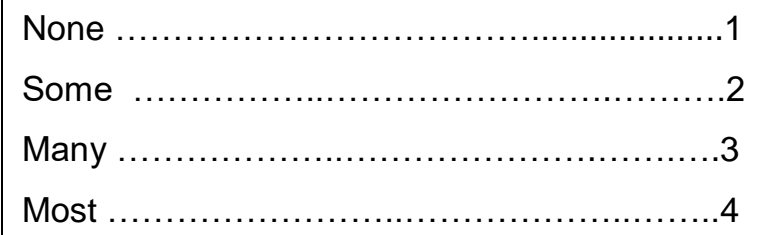 & \\
\hline
\end{tabular}




\begin{tabular}{|c|c|c|c|}
\hline No. (Tablet) & Questions and filters & Coding categories & $\begin{array}{c}\text { Skip } \\
\text { to }\end{array}$ \\
\hline $328(68)$ & $\begin{array}{l}\text { First time parents in your congregation use } \\
\text { a modern method of family planning. }\end{array}$ & 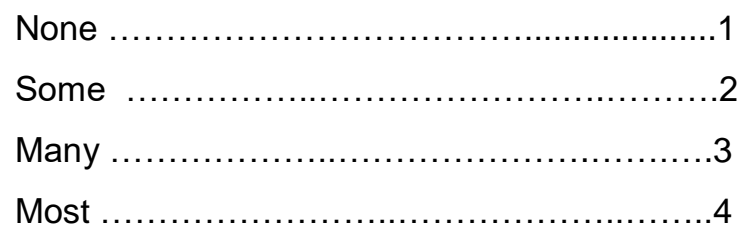 & \\
\hline \multicolumn{4}{|c|}{ SECTION 4: Couple Communication and Family Planning Decision-Making } \\
\hline$(69)$ & \multicolumn{2}{|c|}{$\begin{array}{c}\text { I'm now going to read you a series of statements regarding communicating with your partner } \\
\text { and making family planning decisions }\end{array}$} & \\
\hline $401(70)$ & $\begin{array}{l}\text { Have you ever discussed with your wife } \\
\text { (partner) the number of children you would } \\
\text { like to have? }\end{array}$ & 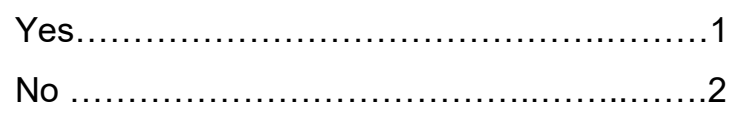 & \\
\hline $402(71)$ & $\begin{array}{l}\text { In the last } 12 \text { months, have you discussed } \\
\text { with your wife (partner) the type of family } \\
\text { planning method you would like to use to } \\
\text { avoid or delay pregnancy? }\end{array}$ & 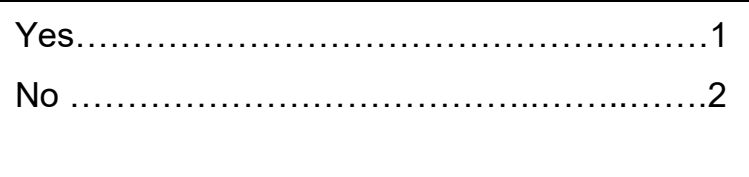 & \\
\hline $403(72)$ & $\begin{array}{l}\text { In the last } 12 \text { months, have you discussed } \\
\text { with your wife (partner) how to obtain a } \\
\text { family planning method to avoid or delay } \\
\text { pregnancy? }\end{array}$ & 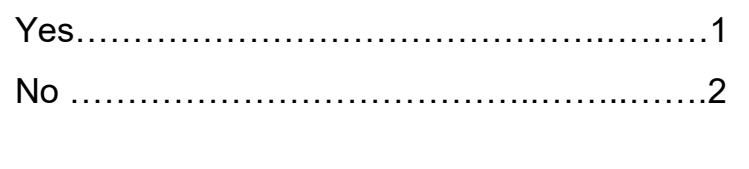 & \\
\hline $404(73)$ & $\begin{array}{l}\text { If you and your wife disagree about using a } \\
\text { modern method of family planning, who } \\
\text { makes the final decision? }\end{array}$ & 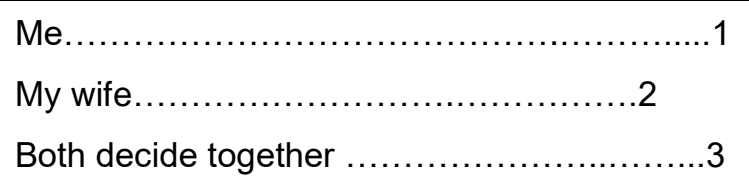 & \\
\hline
\end{tabular}

\section{SECTION 5: Intimate Partner Violence}

\begin{tabular}{|c|c|c|}
\hline (74) & \multicolumn{2}{|c|}{$\begin{array}{l}\text { The next questions are about things that happen to many women and men. To answer these } \\
\text { questions, we will use some cards. Each card contains a word that can describe some actions that } \\
\text { you might have undertaken. I also have three envelopes here. They say 'never', 'sometimes', and } \\
\text { 'often'. Please pick up each card and look at the action. Put the card in the envelope that best } \\
\text { describes the frequency of that action. I am turning my back away so that I cannot see where you are } \\
\text { placing your card). } \\
\text { Have you done the following things to your wife in the last } 12 \text { months... }\end{array}$} \\
\hline $\begin{array}{l}501 \mathrm{a} \\
(75)\end{array}$ & Shouted or yelled at her? & 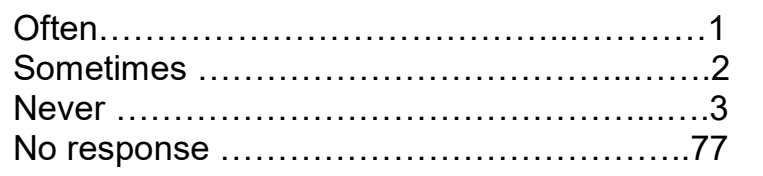 \\
\hline $\begin{array}{l}501 b \\
(76)\end{array}$ & $\begin{array}{l}\text { Threatened to hurt her or someone she cares } \\
\text { about? }\end{array}$ & 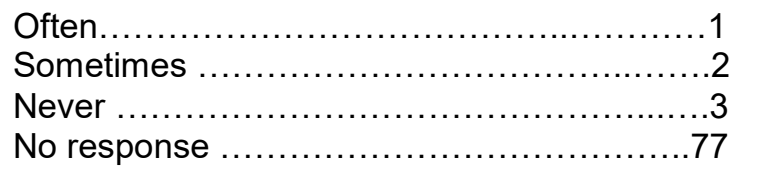 \\
\hline $\begin{array}{l}501 c \\
(77)\end{array}$ & $\begin{array}{l}\text { Pushed her, shaken her, or thrown something at } \\
\text { her? }\end{array}$ & 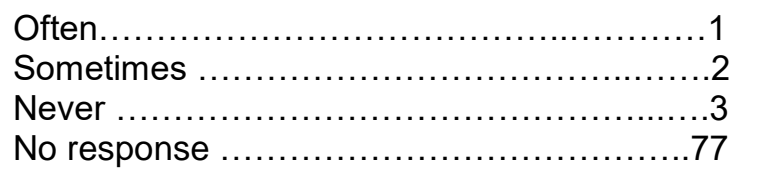 \\
\hline
\end{tabular}


Slapped her or twisted her arm.

501e Punched her with your fist or with something else

(79) that could hurt her.

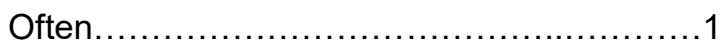

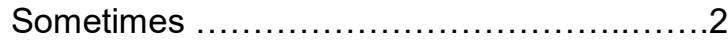

Never ..........................................

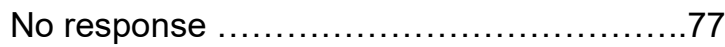

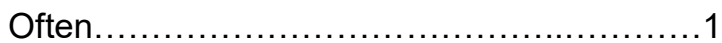

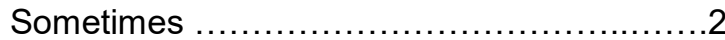

Never ............................................

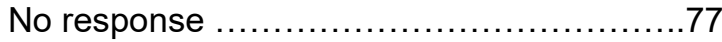

Within the last 12 months .....

Have you physically forced your wife/partner to have sexual intercourse when she expressed that she not want to?

Have you yelled or used physical force against your wife/partner to discourage her from using a modern method of family planning?

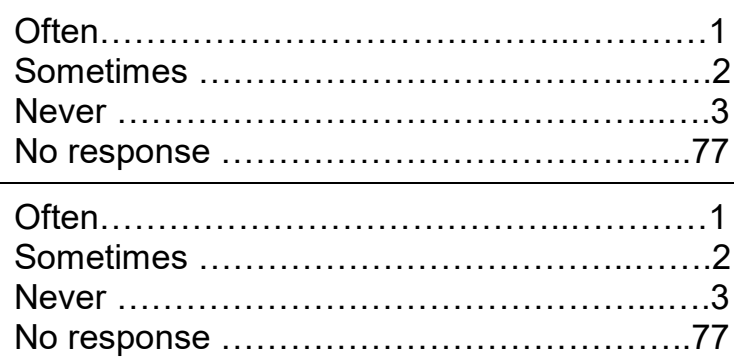

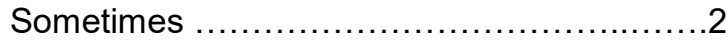

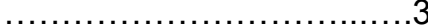

No response ...........

Sometimes $\ldots \ldots \ldots \ldots \ldots \ldots \ldots \ldots \ldots \ldots \ldots \ldots \ldots \ldots . .2$

No response ..................................

\section{Justification of Intimate Partner Violence}

(82) Sometimes a husband is annoyed or angered by things that his wife does. In your opinion is a husband justified in hitting or beating his wife if she...

503a
(83) Goes out without telling him?

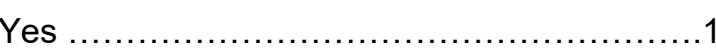

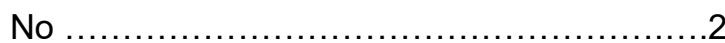

No response .......................................

Neglects the children?

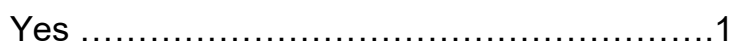

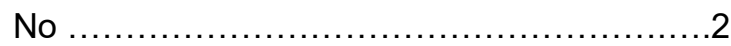

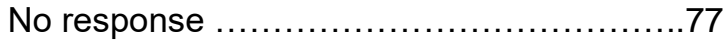

Argues with him?

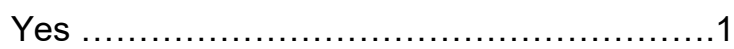

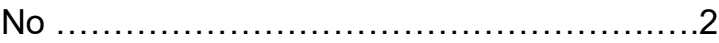

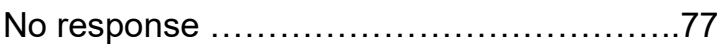

Refuses to have sex with him?

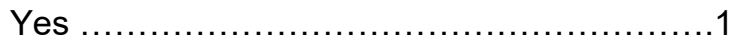

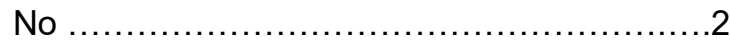

No response .................................77

$503 e$ Burns the food?

Uses a modern method of family planning without his permission

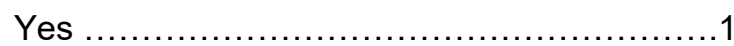

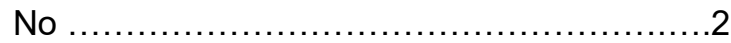

No response $\ldots \ldots \ldots \ldots \ldots \ldots \ldots \ldots \ldots \ldots . \ldots 77$

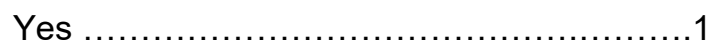

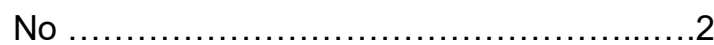

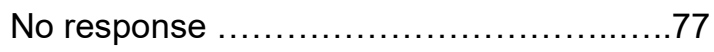

(89) Now I want to ask you a few questions about when you were a child. Think about the time before you were 15 years old and living with parents or another caretaker.

Did you see or hear your mother or other women in your home being beaten by your father or another man living in the home?

Were you threatened with physical punishment in

(91) your home?

506 Did your parents, or caretakers, or any other

(92) adults in the home slap or beat you?

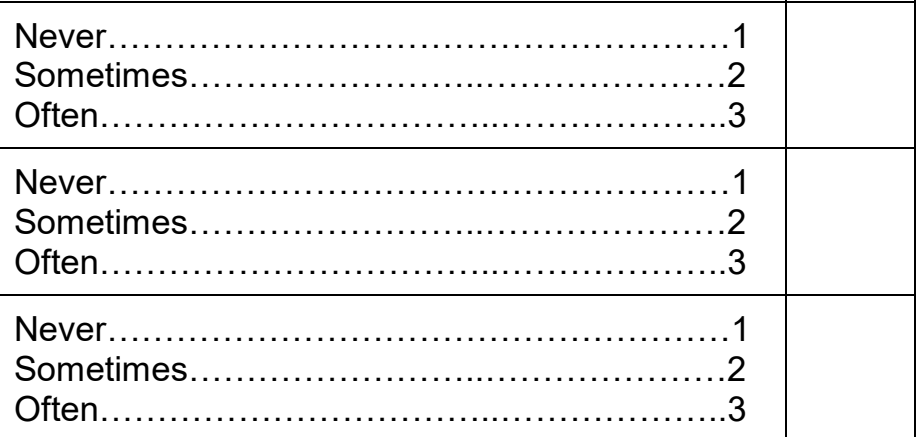


SECTION 6: Attitudes and Norms related to Intimate Partner Violence

\section{Intimate Partner Violence: Outcome Expectation}

(93)

I'm now going to read you a series of statements regarding violence by a husband against his wife, and then I will ask you if you strongly agree, agree, disagree or strongly disagree on each of them.

601 A husband beats his wife to correct her bad

(94) behavior.

Strongly agree..............................

Agree............................................ 2

Disagree..................................... 3

Strongly disagree $\ldots \ldots \ldots \ldots \ldots \ldots \ldots \ldots \ldots \ldots . \ldots \ldots$

Strongly agree.....................................1

602 A husband beating his wife is a normal part of

(95) married life.

Agree. .2

Disagree......................................

Strongly disagree $\ldots \ldots \ldots \ldots \ldots \ldots \ldots \ldots \ldots \ldots \ldots$

Strongly agree....................................

603 If the neighbors see or hear a husband beating

(96) his wife, they will try to stop him

Agree .2

Disagree. .3

Strongly disagree. .4

Intimate Partner Violence: Attitudes, Perceived Control and Intentions

I want to read to you a few more statements. Please tell me how much you agree with each statement. Sometimes I will ask you for slightly different answers but I will tell you when we get to those statements.

604 According to the scripture a husband is supposed

(98) to discipline his wife.

Strongly agree ................................... 1

Agree

.2

Disagree.......................................

Strongly disagree.............................. 4

Extremely important...............................

Important............................................

605 Giving equal weight to what my wife (partner)

(99) says in making decisions is to me.

606 If a man does not beat his wife, people will think

(100) he is not manly.

Unimportant..................................... 3

Extremely unimportant............................. 4

Strongly agree......................................

Agree ................................................. 2

Disagree..........................................

Strongly disagree.................................. 4

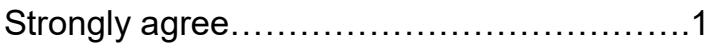

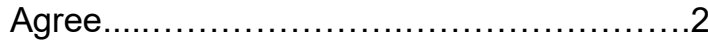

Disagree......................................... 3

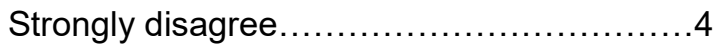




\section{Intimate Partner Violence: Injunctive Norms}

(102)

For this next set of questions, I will read a series of statements. For each statement, I want to know what you think people expect others to do. You can say strongly agree, agree, disagree or strongly disagree.

608 People in this congregation expect a husband to

(103) force his wife to have sex even when she does not want to

609 People in this congregation think it is ok for a

(104) husband to beat his wife at times

Strongly agree...................................

Agree.........................................

Disagree......................................

Strongly disagree $\ldots \ldots \ldots \ldots \ldots \ldots \ldots \ldots \ldots \ldots \ldots$

Strongly agree.................................. 1

Agree.................................................2

Disagree.......................................

Strongly disagree...............................4

Strongly agree ....................................1

610 Faith leaders think it is ok for a husband to beat

(105) his wife at times

Agree............................................

Disagree........................................... 3

Strongly disagree................................ 4

Strongly agree ................................... 1

611 Faith leaders think it is ok for a husband to force

(106) his wife to have sex even when she does not want to

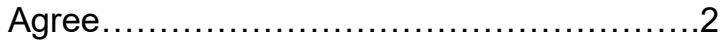

Disagree.......................................

Strongly disagree ............................ 4

Strongly agree $\ldots \ldots \ldots \ldots \ldots \ldots \ldots \ldots \ldots \ldots \ldots \ldots \ldots \ldots \ldots \ldots \ldots \ldots \ldots$

612 It is appropriate for a husband to beat his wife at

(107) times

Agree ............................................ 2

Disagree........................................... 3

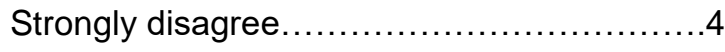

\section{Intimate Partner Violence: Subjective Norms}

613 For matters related to my relationship with my

(108) wife, whose opinion matters to you?

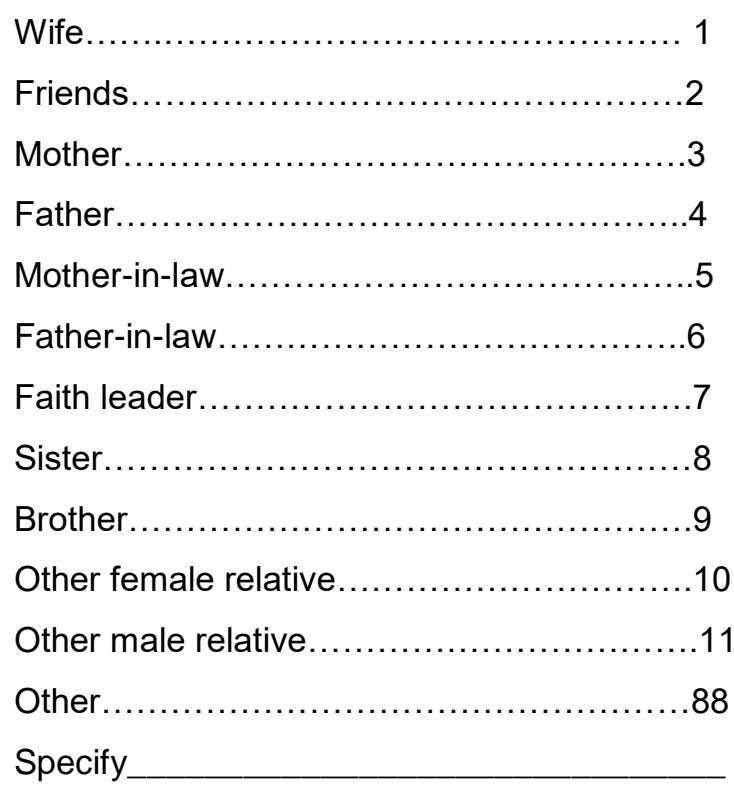


My wife thinks it is ok for me to beat her at times.

Strongly agree. . .1

Agree. .2

Disagree. .3

Strongly disagree. .4

615 My wife thinks it is ok for me to force her to have

(110) sex even when she does not want to.

616 Faith leaders in this congregations think it is ok for

(111) me to beat my wife at times

Extremely likely......................................

Likely..........................................

Unlikely..........................................

Extremely unlikely $\ldots \ldots \ldots \ldots \ldots \ldots \ldots \ldots \ldots \ldots \ldots$

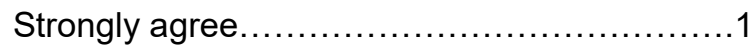

617 People whose opinion is important to me think it is

(112) ok for me to beat my wife at times.

Agree ................................................... 2

Disagree..........................................

Strongly disagree................................ 4

\section{Intimate Partner Violence: Motivation to Comply}

In matters of my relationship with my wife, I want to do what my faith leaders in this congregation want me to do.

In matters of my relationship with my wife, I want to do what my wife wants me to do.

\section{Intimate Partner Violence: Descriptive Norms}

Now I would like to know what people in your congregation actually do. Think about what is normal or typical behavior when you respond to these statements. Do you think that these statements are true for most, many, some or none of the newly married couples or first time parents in this congregation?

A husband beats his wife

A husband forces his wife to have sex even when

Strongly agree $\ldots \ldots \ldots \ldots \ldots \ldots \ldots \ldots \ldots \ldots \ldots \ldots \ldots \ldots \ldots \ldots \ldots$

Agree ...........................................

Disagree.......................................... 3

Strongly disagree.............................. 4

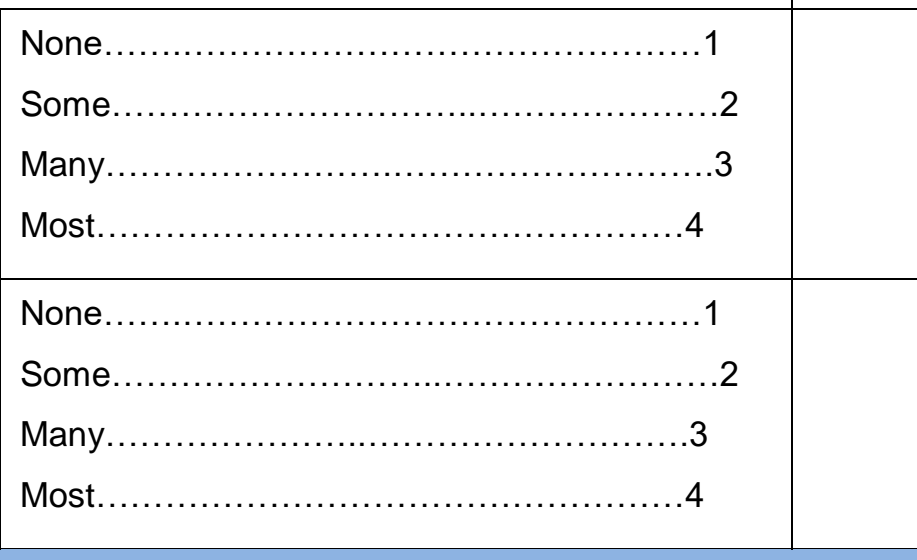


I want to read to you a few more statements. Please tell me whether you how much you agree with the statements.

701 I give equal weight to what my wife says when

(119) making a decision

Strongly agree ..................................

Agree. .2

Disagree.......................................... 3

Strongly disagree............................... 4

702 People whose opinions are important to me,

(120) approve of the husband sharing in the household work such as doing dishes, cleaning and cooking.

I believe men and women were created equal.

704 My wife can express her opinion even if I disagree.

Strongly agree...................................1

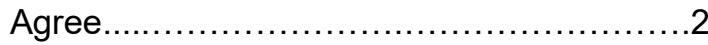

Disagree....................................... 3

Strongly disagree............................... 4

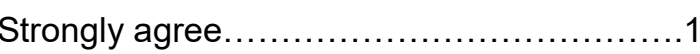

Agree............................................ 2

Disagree........................................ 3

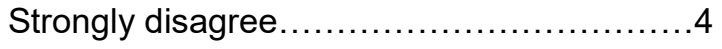

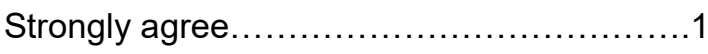

Agree................................................ 2

Disagree....................................... 3

Strongly disagree .............................. 4

705 People whose opinions are important to me, approve of the husband sharing in the responsibilities of child care

Strongly agree ................................... 1

Agree ..............................................

Disagree.....................................

Strongly disagree............................. 4

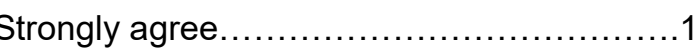

Agree...........................................

Disagree......................................

Strongly disagree............................... 4

Strongly agree ................................... 1

Most newly married couples and first time parents that I know in this congregation approve of the

(125) husband sharing in the household work such as washing dishes, cleaning and cooking

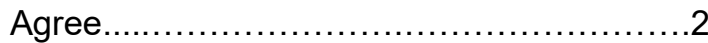

Disagree..........................................

Strongly disagree................................. 4

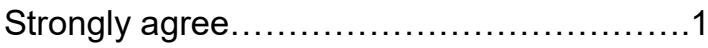

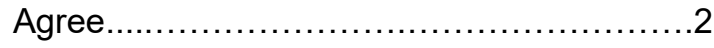

Disagree.........................................

Strongly disagree.............................. 4 
My wife (partner) thinks we should both share in the house work such as doing dishes, cleaning and cooking.

710 My wife (partner) thinks we should both share in

(128) the responsibility of child care.

Strongly agree...............................

Agree......................................2

Disagree................................

Strongly disagree...........................

Strongly agree............................1

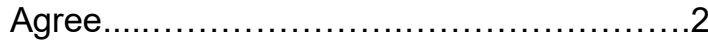

Disagree.....................................

Strongly disagree $\ldots \ldots \ldots \ldots \ldots \ldots \ldots \ldots \ldots \ldots 4$

Strongly agree..............................

711 Faith leaders in this congregation think we should

(129) both share in the responsibility of child care.

Agree.

Disagree.

Strongly disagree $\ldots \ldots \ldots \ldots \ldots \ldots \ldots \ldots \ldots \ldots \ldots$

Strongly agree...............................

Agree.

Disagree...................................

Strongly disagree...........................4

\section{Gender and Positive Masculinities: Descriptive Norms}

Now I would like to know what people in your congregation actually do. Think about what is normal or typical behavior when you respond to these statements. Do you think that these statements are true for most, many, some or none of the people in this congregation? both share in the house work such as doing dishes, cleaning and cooking.
. .2

3

.2

1

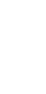

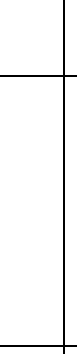

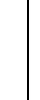

4

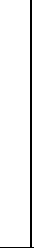

4


